\title{
PROTOCOL TO AMEND THE FRAMEWORK AGREEMENT ON ENHANCING ASEAN ECONOMIC CO-OPERATION ${ }^{1}$ \\ Bangkok, 15 December 1995
}

[The Heads of State or of Government of the Member States of ASEAN]

Recalling the Framework Agreement on Enhancing ASEAN Economic Cooperation ('the Agreement') signed on 28 January at the Fourth Summit Meeting held in Singapore;

Desiring to expedite the implementation of the Common Effective Preferential Tariff (CEPT) Scheme for the ASEAN Free Trade Area (AFTA);

Have agreed as follows:

\section{Article 1}

Article 2, section A, paragraph 1 of the Agreement shall be amended by deleting the expression ' 15 years' and substituting it with the expression ' 10 years (beginning 1 January 1993)'.

\section{Article 2}

The following shall be inserted after Article 12 as a new Article 12A to the Agreement:

\section{“Accession of New Members}

New Members of ASEAN shall accede to the Agreement on terms and conditions consistent with it and which have been agreed between them and the existing Members of ASEAN."

\section{Article 3}

This Protocol shall enter into force upon the deposit of instruments of ratification or acceptance by all signatory governments with the Secretary-General of ASEAN which shall be done not later than 1 January 1996.

This Protocol shall be deposited with the Secretary-General of ASEAN, who shall promptly furnish a certified copy thereof to each Member Country.

Done at Bangkok, . . . in a single copy in the English language.

\footnotetext{
1 Text from: Fifth ASEAN Summit-Meeting of the ASEAN Heads of Government - Bangkok 14 15 December 1995 p.86. For the Framework Agreement, see Vol. 2, p. 412.

Asian Yearbook of International Law, Volume 6 (Ko Swan Sik et al., eds.

${ }^{\circ}$ Kluwer Law International; printed in the Netherlands), pp. 501-518
} 